THE FIRST WORLD WAR 


\section{CONTEXT AND COMMENTARY}

Series Editor: ARTHUR POLLARD

Published titles

J. A. V. Chapple

SCIENCE AND LITERATURE IN THE NINETEENTH CENTURY

Pamela Horn

LIFE AND LABOUR IN RURAL ENGLAND, 1760-1850

Elisabeth Jay

FAITH AND DOUBT IN VICTORIAN BRITAIN

Robin Headlam Wells

SHAKESPEARE, POLITICS AND THE STATE

Dominic Hibberd

THE FIRST WORLD WAR

Norman Page

THE THIRTIES IN BRITAIN

Stephen Prickett

ENGLAND AND THE FRENCH REVOLUTION

Alan and Dorothy Shelston

THE INDUSTRIAL CITY, 1820-1870

Forthcoming titles

Roger Richardson

REVOLT AND RESTORATION IN THE SEVENTEENTH CENTURY

Alan Downie

LITERATURE AND POLITICS 1678-1780 


\section{THE FIRST WORLD WAR}

Dominic Hibberd

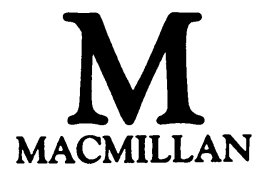




\section{(C) Dominic Hibberd 1990}

All rights reserved. No reproduction, copy or transmission of this publication may be made without written permission.

No paragraph of this publication may be reproduced, copied or transmitted save with written permission or in accordance with the provisions of the Copyright, Designs and Patents Act 1988, or under the terms of any licence permitting limited copying issued by the Copyright Licensing Agency, 33-4 Alfred Place, London WC1E 7DP.

Any person who does any unauthorised act in relation to this publication may be liable to criminal prosecution and civil claims for damages.

First published 1990

Published by

MACMILLAN EDUCATION LTD

Houndmills, Basingstoke, Hampshire RG21 2XS

and London

Companies and representatives

throughout the world

Typeset by Wessex Typesetters

(Division of The Eastern Press Ltd)

Frome, Somerset

British Library Cataloguing in Publication Data The First World War.

1. English Literature, 1900-1945 - Anthologies

I. Hibberd, Dominic

820.800912

ISBN 978-0-333-39777-0 ISBN 978-1-349-20712-1 (eBook)

DOI 10.1007/978-1-349-20712-1 


\section{Contents}

List of Plates

Acknowledgements

Editor's Preface

vi
viii
$x i$

1. Introduction 1

2. The Coming of the War 4

3. War to End War: August 1914-December 1915

4. The Year of the Somme: 1916

5. Dulce et Decorum Est: 1917

6. Retreat and Victory: January-November $1918 \quad 156$

7. Peace to End Peace 182

Chronological Table $\quad 198$

Bibliography 205

Index 210 


\section{List of Plates}

1. Injured Innocence by Bernard Partridge, Punch (31 May 1916) page 361. The German Ogre stands on the torn 'scrap of paper', the treaty which had guaranteed Belgian neutrality. Behind him is Bernhardi's slogan, 'Weltmacht oder Niedergang' ('World-power or downfall').

Photograph (C) Bodleian Library, from N. $2706 d 10$.

2. The Merry-Go-Round by Mark Gertler (1916). ' . . in this combination of blaze, and violent and mechanised rotation and complete involution, utterly mindless intensity of sensational extremity, you have made a real and ultimate revelation' (D. H. Lawrence to Gertler, 9 October 1916).

Photograph (C) Tate Gallery.

3. The Signing of the Peace in the Hall of Mirrors, 28 June 1919 by William Orpen. In front of the leaders of the victorious countries, German representatives sign the Treaty of Versailles. The overwhelming architecture and crooked mirrors make a mocking background. One of the reflected silhouettes is Orpen himself, official British artist at the conference.

Photograph (C) The Trustees of the Imperial War Museum.

4. The Menin Road 1918 by Adrian Hill. British troops pass through the site of the old town gate in the walls of Ypres. Plates 4 and 5 were published together as No 1 in a series 'Ten Years After 1918-1928' in Answers Magazine (20 October 1928).

Photograph (C) Bodleian Library, from John Johnson Collection: Great War. Box 24.

5. The Menin Gate 1928 by Adrian Hill. The new gate, completed in 1927, is a memorial to the armies of the 


\section{List of Plates vii}

British Empire who held the Ypres Salient; it bears the names of 54889 soldiers who have no known graves. Photograph (C) Bodleian Library, from John Johnson Collection as above. 


\section{Acknowledgements}

The author and publishers wish to thank the following who have kindly given permission for the use of copyright material: Carcanet Press Ltd. for extracts from War Letters by Ivor Gurney, 1983; Chatto and Windus, The Hogarth Press on behalf of the Estate of Wilfred Owen for 'Dulce et Decorum Est' by Wilfred Owen from The Complete Poems and Fragments ed. J. Stallworthy, The Hogarth Press, 1983; and on behalf of the Executors of the H. G. Wells Estate for extracts from $\mathrm{Mr}$ Britling Sees it Through by H. G. Wells, Chatto and Windus; Curtis Brown Group Ltd on behalf of the Estate of Sir Winston Churchill for extracts by Winston S. Churchill from Sunday Pictorial, 20 May 1917. Copyright (C) the Estate of Sir Winston Churchill; Faber and Faber Ltd for an extract from In Parenthesis by David Jones, 1937; William Heinemann Ltd for material from The Middle Parts of Fortune by Frederick Manning, Peter Davies, 1977; David Higham Associates Ltd for an extract from 'Meditation of the Waking English Officer' from The End of the War by Herbert Read, Faber and Faber, 1933; Macmillan, London and Basingstoke, with Cambridge University Press, Inc. for material from The Economic Consequences of the Peace by J. M. Keynes, 1919; and with Michael Gibson for 'Breakfast' by W. W. Gibson, The Nation, 17 October 1914; Macmillan Publishing Company for 'Sisteen Dead Men' from The Poems of W. B. Yeats ed. Richard J. Finneran. Copyright (C) 1924 by Macmillan Publishing Company, renewed 1952 by Bertha Georgie Yeats; John Murray (Publishers) Ltd for extracts from Poor Bloody Infantry by Bernard Martin, 1987; Peters Fraser and Dunlop for extracts from 'Third Ypres' from Poems of Many Years by Edmund Blunden, William Collins Sons and Co. Ltd; Pillans and Wilson Ltd for an extract from The Wine Press: A Tale of War by Alfred Noyes, William Blackwood and Sons, 1913; The Bertrand Russell Estate for an extract from The Labour Leader, 10 September 1914; 
George T. Sassoon for Siegfried Sassoon's public protest, 1917 and an extract from Memoirs of an Infantry Officer by Siegfried Sassoon; with Viking Penguin, Inc. for 'The Rear Guard', 'Does it Matter?' and 'Passing the New Menin Gate' from The Collected Poems by Siegfried Sassoon. Copyright (C) $1918 / 1920$ by E. P. Dutton and Co., Inc. 1936, 1946, 1947, 1948 by Siegfried Sassoon; Sidgewick and Jackson Ltd for 'The Volunteer' from The Volunteer and Other Poems by Herbert Asquith, 1916; Timothy d'Arch Smith for an extract from 'The Answer' from Poetical Works by Gilbert Frankau, Chatto and Windus, 1923; The Society of Authors with Mrs Nicolete Gray on behalf of the Laurence Binyon Estate for 'The Test' by Laurence Binyon; and on behalf of The Bernard Shaw Estate for an extract from Common Sense About the War by Bernard Shaw, 1930; The Estate of H. M. Tomlinson for an extract from All Our Yesterdays by H. M. Tomlinson, William Heinemann, 1930; Unwin Hyman Ltd for material from Principles of Social Reconstruction by Bertrand Russell; and a letter from A. G. West, in Autobiography Volume II by Bertrand Russell, 1968; and 'Two Years After' from $A$ Ballad of Four Brothers by George Willis, 1921; A. P. Watt Ltd on behalf of the Literary Executors of the Estate of H. G. Wells for material from In the Fourth Year by H. G. Wells and 'Why Britain Went to War' from The War That Will End War by H. G. Wells. Every effort has been made to trace all copyright holders, but if any have been inadvertently overlooked the publishers will be pleased to make the necessary arrangement at the first opportunity. 
For my Father 


\section{Editor's Preface}

J. H. Plumb has said that 'the aim of (the historian) is to understand men both as individuals and in their social relationships in time. "Social" embraces all of man's activities economic, religious, political, artistic, legal, military, scientific - everything, indeed, that affects the life of mankind.' Literature is itself similarly comprehensive. From Terence onwards writers have embraced his dictum that all things human are their concern.

It is the aim of this series to trace the interweavings of history and literature, to show by judicious quotation and commentary how those actually working within the various fields of human activity influenced and were influenced by those who were writing the novels, poems and plays within the several periods. An attempt has been made to show the special contribution that such writers make to the understanding of their times by virtue of their peculiar imaginative 'feel' for their subjects and the intensely personal angle from which they observe the historical phenomena that provide their inspiration and come within their creative vision. In its turn the historical evidence, besides and beyond its intrinsic importance, serves to 'place' the imaginative testimony of the writers.

The authors of the several volumes in this series have sought to intermingle history and literature in the conviction that the study of each is enhanced thereby. They have been free to adopt their own approach within the broad general pattern of the series. The topics themselves have sometimes also a particular slant and emphasis. Commentary, for instance, has had to be more detailed in some cases than in others. All the contributors to the series are at one, however, in the belief (at a time when some critics would not only divorce texts from their periods but even from their authors) that literature is the creation of actual men and women, actually living in an identifiable set of historical circumstances, themselves both the creatures and the creators of their times.

ARTHUR POLLARD 